\title{
ANALISIS KEMAMPUAN KEUANGAN DAERAH DALAM UPAYA PELAKSANAAN OTONOMI DAERAH DI KABUPATEN MUSI RAWAS PERIODE 2007-2011
}

\author{
Eko Amanda ${ }^{1}$, Zulgani $^{2}$ \\ ${ }^{1)}$ Prodi Keuangan Daerah FEB Universitas Jambi \\ ${ }^{2)}$ Prodi Ekonomi Pembangunan FEB Universitas Jambi \\ rizkonjayadi21@gmail.com
}

\begin{abstract}
Abstrak
Penelitian ini sebagai salah satu tolak ukur keberhasilan otonomi daerah dengan melihat kemampuan keuangannya. Sehingga berdasarkan hal tersebut, penelitian ini bertujuan untuk mengetahui kemampuan keuangan daerah dalam upaya pelaksanaan otonomi daerah di Kabupaten Musi Rawas. Adapun alat analisis yang digunakan adalah kontribusi PAD terhadap APBD, Rasio Kemandirian Keuangan Daerah, Indeks Kemampuan Rutin, Rasio Keserasian,. Data yang digunakan merupakan data sekunder dari instansi pemerintah terkait, yakni mengenai Anggaran Pendapatan Dan Belanja Daerah (APBD) dalam kurun waktu 2006-2012. Hasil penelitian, Kontribusi PAD terhadap APBD masih kuran yaitu sebesar 4,33 \%. Rasio Kemandirian Keuangan Daerah memperoleh nilai rata-rata sebesar 4,56 \%, atau berada pada pola hubungan Instruktif. Rasio Derajat Desentralisasi Fiskal menunjukan kemampuan keuangan daerah masih kurang yaitu sebesar 4,33 \%. Pada Rasio Indeks Kemampuan Rutin kemampuan daerah masih kurang yaitu sebesar 7,40 \%. Rasio Keserasian menunjukan bahwa belanja rutin lebih besar daripada belanja pembangunan yaitu 60,67 \% dan 39,22\%. Untuk meningkatkan kemampuan keuangan daerah Kabupaten Musi Rawas perlu menginsentifikasi penerimaan PAD, dengan mengoptimalkan semua sumber keuangan yang ada.
\end{abstract}

Kata Kunci : keuangan daerah, otonomi daerah

\begin{abstract}
This research is a measure of the success of regional autonomy by looking at its financial capacity. So based on this, this study aims to determine the regional financial capacity in the effort to implement regional autonomy in Musi Rawas Regency. The analysis tools used are the contribution of PAD to the Regional Budget, Regional Financial Independence Ratio, Routine Capability Index, Harmony Ratio ,. The data used is secondary data from related government agencies, namely regarding the Regional Revenue and Expenditure Budget (APBD) for the period 2006-2012. The results showed that the PAD contribution to the APBD was still low, namely at $4.33 \%$. The Regional Financial Independence Ratio obtained an average value of $4.56 \%$, or is in the Instructive relationship pattern. The ratio of degree of fiscal decentralization shows that regional financial capacity is still lacking, namely 4.33\%. In the Routine Ability Index Ratio, the regional ability is still lacking, namely at $7.40 \%$. The compatibility ratio shows that routine expenditure is greater than development expenditure, namely $60.67 \%$ and $39.22 \%$. To improve the regional financial capacity, Musi Rawas District needs to identify revenue from PAD, by optimizing all available financial sources.
\end{abstract}

Keywords: regional finance, regional autonomy 


\section{PENDAHULUAN}

Tujuan dari pemberian Otonomi Daerah sebagaimana dijelaskan dalam UU No. 32 Tahun 2004 adalah untuk mempercepat terwujudnya kesejahteraan masyarakat melalui peningkatan pelayanan, pemberdayaan dan peran serta masyarakat. Disamping itu melalui otonomi luas, daerah diharapkan mampu meningkatkan daya saing dengan memperhatikan prinsip demokrasi, pemerataan, keadilan, keistimewaan dan kekhususan serta potensi dan keanekaragaman daerah dalam sistem Negara Kesatuan Republik Indonesia.

Dalam penyelenggaraan otonomi daerah, pemerintah daerah dituntut untuk dapat menjalankan sistem roda pemerintahan yang efektif, efisien, dan mampu mendorong peran serta masyarakat dalam meningkatkan pemerataan dan meminimalisir kesenjangan serta keadilan dengan mengembangkan seluruh potensi yang dimiliki oleh masing-masing daerah. Keberhasilan otonomi daerah tidak terlepas dari kemampuan dalam bidang keuangan.

Menurut UU 32 Tahun 2004 tentang Pemerintah Daerah dalam pasal 1 huruf 1 "Daerah otonom," selanjutnya disebut daerah, adalah kesatuan masyarakat hukum yang mempunyai batas-batas wilayah yang berwenang mengatur dan mengurus urusan pemerintahan dan kepentingan masyarakat setempat menurut prakarsa sendiri berdasarkan aspirasi masyarakat dalam sistem Negara Kesatuan Republik Indonesia.

Pengertian daerah otonom dimaksud agar disuatu daerah dapat berkembang sesuai dengan kemampuannya sendiri yang tidak bergantung kepada pemerintah pusat, oleh karena itu daerah otonom harus mempunyai kemampuan sendiri untuk mengurus dan mengatur rumah tangganya sendiri melalui sumber-sumber pendapatan daerah yang

dimiliki. Hal ini meliputi semua kekayaan yang dikuasai oleh daerah dengan batasbatas kewenangan yang ada dan selanjutnya digunakan untuk membiayai semua kebutuhan dalam rangka penyelenggaraan urusan rumah tangganya sendiri. Jadi agar daerah dapat menjalankan kewajibannya dengan sebaik-baiknya perlu ada sumber pendapatan daerah, karena semakin besar keuangan daerah maka akan semakin besar juga kemampuan daerah dalam membiayai rumah tangganya sendiri.

Agar implementasi otonomi daerah dapat berhasil dengan baik paling tidak ada 5 (lima) strategi yang harus diperhatikan, yaitu (Mulyanto, 2001): (i) Self Regular Power, dalam arti kemampuan mengatur dan melaksanakan OTDA demi kepentingan masyarakat di daerahnya; (ii) Self Modifying Power, berupa kemampuan menyesuaikan terhadap peraturan yang telah ditetapkan secara nasional sesuai dengan kondisi daerah, termasuk terobosan inovatif kearah kemajuan dalam menyikapi potensi daerah; (iii) Creating Local Political Support, dalam arti penyelenggaraan pemerintahan daerah yang mempunyai legitimasi kuat dari masyarakatnya, baik pada posisi Kepala Daerah sebagai eksekutif maupun DPRD sebagai pemegang kekuasaan legislatif; (iv) Managing Finansial Resources, dalam arti mampu mengembangkan kompetensi dalam mengelola secara optimal sumber penghasilan dan keuangan guna pembiayaan aktivitas pemerintahan, pembangunan dan pelayanan masyarakat; serta (v) Developing Brain Power, dalam arti membangun SDM (Sumber Daya Manusia) yang handal dan selalu bertumpu pada kapabilitas menyelesaikan masalah.

Aspek keuangan merupakan salah satu dasar kriteria untuk dapat mengetahui secara nyata kemampuan daerah dalam mengurus rumah tangganya sendiri. Kemampuan daerah yang dimaksud adalah sampai sejauh mana daerah dapat menggali sumber-sumber

keuangan sendiri guna membiayai kebutuhan keuangan daerahnya tanpa harus menggantungkan diri pada dana bantuan dari pemerintah pusat kepada pemerintah daerah yang lebih tinggi. 
Kemampuan keuangan daerah dalam era otonomi daerah sering diukur dengan menggunakan kinerja Pendapatan Asli Daerah (PAD). Besar-kecilnya penerimaan PAD seringkali dihubungkan dengan keberhasilan daerah dalam menjalani otonomi daerah. karena semakin besar PAD maka dikatakan semakin mampu suatu daerah tersebut untuk mencapai keberhasilan otonomi daerah.

PAD adalah penerimaan yang diperoleh dari sektor pajak daerah, retribusi daerah, hasil perusahaan milik daerah, hasil pengeloalaan kekayaan daerah yang dipisahkan, dan lain-lain pendapatan yang sah. PAD merupakan salah satu komponen sumber pendapatan daerah sebagaimana yang telah diatur dalam pasal 79 undang-undang nomor 22 tahun 1999 tentang pemerintahan daerah, berdasarkan pasal 79 UU 22/1999 disimpulkan bahwa sesuatu yang diperoleh pemerintah daerah yang dapat diukur dengan uang karena kewenangan (otoritas) yang diberikan masyarakat dapat berupa hasil pajak daerah dan retribusi daerah.

PAD merupakan salah satu tolok ukur untuk menentukan tingkat kemampuan suatu daerah dalam membiayai rumah tangganya sendiri, untuk itu daerah di tuntut untuk mampu menggali potensi-potensi yang ada di suatu daerah dalam meningkatkan PAD di daerah itu sendiri, agar daerah bisa mandiri dan mengurangi ketergantungan dana bantuan yang bersumber dari pusat dan dapat mencapai tujuan dari otonomi daerah.

Secara Umum Total PAD dan Dana Perimbangan Kabupaten Musi Rawas mengalami fluktuatif tiap tahunnya. Pada tahun 2006 Total PAD Musi Rawas sebesar Rp.

25.598.297.042. Sedangkan pada tahun 2012 Total PAD sebesar Rp. 72.528.176.485, atau meningkat $64,7 \%$ selama 7 tahun, adapun rata-rata perkembangan PAD dari tahun 2006 sampai 2012 yaitu sebesar 13,37\%. Adapun total dari dana perimbangan pada tahun 2006 sebesar 590.718.677.845. Sedangkan pada tahun 2012 total dana perimbangan sebesar Rp. 1.163.513.138.843 atau meningkat sebesar 49,2\%. Sedangkan rata-rata perkembangan dana perimbangan per tahun dari tahun 2006 sampai 2012 sebesar $9,6 \%$.

\section{Tujuan Penelitian}

1. Untuk menghitung kontribusi PAD terhadap Anggaran Pendapatan dan Belanja Daerah tahun 2006-2012 dalam menunjang pelaksanaan Otonomi Daerah di Kabupaten Musi Rawas.

2. Tujuan yang hendak dicapai dalam penelitian ini adalah untuk menganalisis kemampuan keuangan daerah Kabupaten Musi Rawas dalam upaya mendukung pelaksanaan otonomi daerah periode tahun 2006-2012.

\section{METODE PENELITIAN} Jenis Data

Di dalam penelitian ini data yang digunakan adalah data sekunder yang merupakan data berkala dari tahun 2006-2012. Data sekunder merupakan data yang sudah ada dan dokumen-dokumen lain yang diperlukan dalam penelitian ini. Adapun data sekunder yang diperlukan antara lain:

a. APBD (Anggaran Pendapatan dan Belanja Daerah) Kabupaten Musi Rawas periode 2006-2012.

b. Data Produk Domestik Regional Bruto (PDRB) Kabupaten Musi Rawas tahun 2013.

c. Data Jumlah Penduduk Kabupaten Musi Rawas Dalam Angka Tahun 2013.

d. PAD Kabupaten Musi Rawas selama periode 2006-2012. 


\section{Sumber Data}

1. DPPKAD (Dinas Pendapatan dan Pengelolaan Keuangan Daerah) Kabupaten Musi Rawas.

2. BPS (Badan Pusat Statistik) Kabupaten Musi Rawas.

\section{Metode Analisis Data}

Untuk menjawab tujuan penelitian pertama, yaitu untuk menganalisis konstribusi PAD terhadap APBD tahun 2006-2012 dalam menunjang mendukung pelaksanaan otonomi daerah di Kabupaten Musi Rawas, maka digunakan rumus:

$$
K=\frac{\sum P A D}{\sum A P B D} \times 100 \%
$$

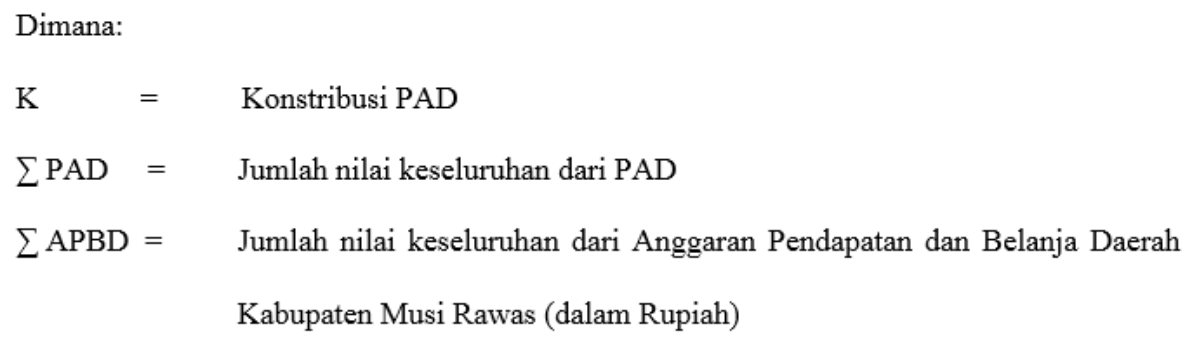

Untuk mengetahui berapa besarnya Konstribusi Pendapatan Asli Daerah terhadap Anggaran Pendapatan dan Belanja Daerah dalam menunjang pelaksanaan Otonomi Daerah di Kabupaten Musi Rawas digunakan rumus diatas. Untuk menjawab tujuan penelitian kedua, yaitu untuk mengetahui tingkat kemampuan keuangan daerah Kabupaten Musi Rawas maka digunakan beberapa indikator kemampuan keuangan daerah terdiri dari:

\section{a. Rasio Kemandirian Keuangan Daerah}

$$
\text { Rasio Kemandirian }=\frac{\text { Pendapatan Asli Daerah }}{\text { Bantuan Pemerintah Pusat } / \text { Provinsi }+ \text { Pinjaman }} \times 100 \% \text {. }
$$

Tabel 1. Skala Interval Rasio Kemandirian Keuangan Daerah

\begin{tabular}{|l|c|c|}
\hline \multicolumn{1}{|c|}{$\begin{array}{c}\text { Kemampuan } \\
\text { Keuangan Daerah }\end{array}$} & RKKD & Pola Hubungan \\
\hline Rendah Sekali & $0,00 \%-25,00 \%$ & Instruktif \\
\hline Rendah & $25,01 \%-50,00 \%$ & Konsultatif \\
\hline Sedang & $50,01 \%-75,00 \%$ & Partisipatif \\
\hline Tinggi & $75,01 \%-100 \%$ & Delegatif \\
\hline
\end{tabular}

Sumber: Wulandari (2001)

Rasio ini menggambarkan tingkat ketergantungan daerah terhadap sumber dana ekstern. Semakin tinggi rasio kemandirian, berarti tingkat ketergantungan daerah terhadap bantuan pihak ekstern (terutama pemerintah pusat dan provinsi) semakin rendah, demikian pula sebaliknya. 


\section{b. Rasio Derajat Desentralisasi Fiskal}

Untuk mengukur Derajat Desentralisasi Fiskal (DDF):

$$
D D F=\frac{P A D t}{T P D t} \times 100 \%
$$

Dimana:

DDF $=$ Derajat Desentralisasi Fiskal

PADt $=$ Total PAD tahun $\mathrm{t}$

TPDt $=$ total Penerimaan Daerah tahun $\mathrm{t}$

Berdasarkan hasil perhitungan kedua rumus diatas, maka digunakan skala interval untuk mengetahui kemampuan keuangan.

Tabel 2. Skala Interval Derajat Desentralisasi Fiskal

\begin{tabular}{|c|c|}
\hline$\%$ & Kemampuan Keuangan Daerah \\
\hline $0,00-10,00$ & Sangat Kurang \\
$10,01-20,00$ & Kurang \\
\hline $20,01-30,00$ & Cukup \\
\hline $30,01-40,00$ & Sedang \\
\hline $40,01-50,00$ & Baik \\
\hline$>50,00$ & Sangat Baik \\
\hline
\end{tabular}

Semakin tinggi kemandirian suatu daerah menunjukkan bahwa daerah tersebut semakin mampu membiayai pengeluarannya sendiri tanpa bantuan dari pemerintah pusat.Apabila dipadukan dengan derajat desentralisasi fiskal yang digunakan untuk melihatkonstribusi PAD terhadap pendapatan daerah secara keseluruhan, maka akan terlihat kinerjakeuangan daerah secara utuh.

\section{c. Rasio Indeks Kemampuan Rutin}

Indeks Kemampuan Rutin (IKR) dapat dihitung dengan menggunakan rumus sebagai berikut:

$$
I K R=\frac{P A D}{\text { Total Pengeluaran Rutin }} \times 100 \%
$$


Tabel 3. Skala Interval Indeks Kemampuan Rutin

\begin{tabular}{|c|c|}
\hline$\%$ & Kemampuan Keuangan \\
\hline $0,00-20,00$ & Saerah \\
\hline $20,01-40,00$ & Kurang Kurang \\
\hline $40,01-60,00$ & Cukup \\
\hline $60,01-80,00$ & Baik \\
\hline $80,01-100,00$ & Sangat Baik \\
\hline
\end{tabular}

Dalam penelitian ini, pengeluaran rutin diperoleh dari bagian belanja operasi, hal ini dikarenakan adanya perubahan peraturan mengenai kelompok belanja dalam Peraturan Pemerintah Nomor 24 Tahun 2005 dan Peraturan Menteri Dalam Negeri Nomor 13 Tahun 2006.

\section{d. Rasio Keserasian}

Keserasian ini menggambarkan bagaimana pemerintah daerah memprioritaskan alokasi dananya pada belanja rutin dan belanja pembangunan secara optimal. Semakin tinggi presentase dana yang dialokasikan untuk belanja rutin berarti presentase belanja pembangunan yang digunakan untuk menyediakan sarana prasarana ekonomi masyarakat cenderung semakin kecil. Secara sederhana rasio keserasian ini dapat diformulasikan sebagai berikut (Mahmudi, 2010).

$$
\begin{aligned}
& \text { Rasio Belanja Operasional }=\frac{\text { Total Belanja Operasi }}{\text { Total Belanja APBD }} \\
& \text { Rasio Belanja Modal }=\frac{\text { Total Belanja Modal }}{\text { Total Belanja APBD }}
\end{aligned}
$$

\section{HASIL DAN PEMBAHASAN}

\section{Kontribusi PAD terhadap Anggaran PAD Tahun Anggaran 2006-2012}

Kontribusi PAD merupakan salah satu indikator dari kebijakan untuk mengukur kemandirian daerah. Semakin tinggi rasio PAD berarti PAD semakin berkontribusi dalam total penerimaan daerah, sehingga daerah memiliki kemandirian keuangan semakin tinggi. Sebaliknya semakin rendah rasio PAD maka peran PAD terhadap total penerimaan daerah semakin kecil, sehingga kemungkinan daerah memiliki kemandirian keuangan semakin rendah.

Adapun hasil perhitungan Kontribusi PAD terhadap APBD Kabupaten Musi Rawas dari tahun 2006 sampai dengan 2012 dapat dilihat pada tabel 5.1 berikut: 
Tabel 4. Kontribusi PAD terhadap APBD Kabupaten Musi Rawas Tahun 2006-2010 (dalam satuan rupiah)

\begin{tabular}{|c|c|c|c|}
\hline $\begin{array}{c}\text { Tahun } \\
\text { Anggaran }\end{array}$ & $\begin{array}{l}\text { PAD } \\
\text { (Rp) }\end{array}$ & $\begin{array}{c}\text { APBD } \\
\text { (Rp) }\end{array}$ & $\%$ \\
\hline 2006 & $25.598 .297 .042,00$ & $631.166 .534 .687,00$ & 4,06 \\
\hline 2007 & $29.504 .973 .615,00$ & $757.248 .857 .584,00$ & 3,90 \\
\hline 2008 & $31.877 .920 .415,70$ & $952.025 .183 .382,00$ & 3,35 \\
\hline 2009 & $31.569 .268 .795,57$ & $804.084 .338 .660,57$ & 3,93 \\
\hline 2010 & $42.713 .015 .778,20$ & 1.001.484.266.579,20 & 4,26 \\
\hline 2011 & $65.469 .334 .676,97$ & $1.231 .376 .695 .408,97$ & 5,32 \\
\hline 2012 & $73.018 .397 .086,40$ & 1.332.838.864.099,65 & 5,48 \\
\hline \multicolumn{3}{|c|}{ Rata-rata } & 4,33 \\
\hline
\end{tabular}

Sumber : Data diolah, 2014

Berdasarkan tabel 4 terlihat bahwa Kontribusi PAD terhadap APBD Kabupaten Musi Rawas dari tahun ke tahun menunjukan keadaan yang tidak stabil dan cenderung berubah-ubah. Pada tahun 2006-2007 tingkat kontibusinya mencapai 4,06\% dan 3,90\% . Selanjutnya pada tahun 2008 mengalami penurunan menjadi 3,35\% dan pada tahun 2009 meningkat menjadi 3,93\%. Pada tahun 2010-2012 selalu mengalami peningkatan kembali sebesar 4,26\% dan 5,32\% sampai 5,48\%. Dari uraian dan perhitungan tabel 5.1 diatas dapat disimpulkan bahwa kontribusi PAD terhadap pembentukan APBD selama lima tahun pada pemerintahan Kabupaten Musi Rawas masih sangat kecil, dimana rata-ratanya sebesar 4,33\%. Rendahnya Kontribusi PAD terhadap APBD disebabkan beberapa faktor, diantaranya karena kurangnya komponen penerimaan PAD yang masih sangat kecil dalam menunjang penerimaan APBD di Kabupaten Musi Rawas.

\section{Rasio Kemandirian Keuangan Daerah}

Hasil Perhitungan Kemandirian Keuangan Daerah dapat dilihat dalam pada tabel 5.

Tabel 5. Perhitungan Rasio Kemandirian Kabupaten Musi Rawas Tahun Anggaran 2006-2012

\begin{tabular}{|c|c|c|c|c|c|c|}
\hline \multirow[t]{2}{*}{ No } & \multirow[t]{2}{*}{ TA } & \multirow[t]{2}{*}{ Total Pendapatan } & $\begin{array}{c}\text { Pendapatan Asli } \\
\text { Daerah }\end{array}$ & $\begin{array}{l}\text { Sumber Pendapatan } \\
\text { Dari Pihak Ekstren }\end{array}$ & $\begin{array}{c}\text { Rasio } \\
\text { Kemandirian }\end{array}$ & Keterangan \\
\hline & & & (Rp) & (Rp) & $(\%)$ & \\
\hline 1 & 2006 & $631.166 .534 .687,00$ & $25.598 .297 .042,00$ & $605.562 .422 .965,00$ & 4,20 & Instruktif \\
\hline 2 & 2007 & $757.248 .857 .584,00$ & $29.504 .973 .615,00$ & $727.743 .883 .969,00$ & 4,05 & Instruktif \\
\hline 3 & 2008 & $952.025 .183 .382,00$ & $31.877 .920 .415,70$ & $920.147 .262 .967,00$ & 3,40 & Instruktif \\
\hline 4 & 2009 & 804.084 .338 .660 .57 & 31.569 .268 .795 .57 & $772.515 .069 .865,00$ & 4,00 & Instruktif \\
\hline 5 & 2010 & $1.001 .484 .266 .579,20$ & $42.713 .015 .778,20$ & $951.837 .065 .801,00$ & 4,49 & Instruktif \\
\hline 6 & 2011 & $1.231 .376 .695 .408,97$ & $65.469 .334 .676,97$ & $1.148 .094 .090 .624,00$ & 5,70 & Instruktif \\
\hline 7 & 2012 & $1.332 .838 .864 .099,65$ & $73.018 .397 .086,40$ & $1.238 .627 .966 .874,25$ & 5,90 & Instruktif \\
\hline & & & ata-rata & & 4,56 & Instruktif \\
\hline
\end{tabular}

Sumber : Data diolah, 2014

Berdasarkan tabel 5 terlihat rasio kemandirian mengalami peningkatan dan penurunan. Pada tahun 2006 rasio kemandirian mencapai 4,23\% dan pada tahun 2007 turun menjadi 4,05\% kemudian tahun 2008 turun lagi menjadi 3,46\%. Selanjutnya pada tahun 2009 sampai 2012 selalu mengalami peningkatan dari 4,09\% dan 4,49\% menjadi $5,70 \%$ sampai kenaikan menjadi 5,90\%. Sehingga rata-rata dari rasio kemandirian adalah 
sebesar 4,56\%. Rasio kemandirian yang masih rendah, dapat dilihat pada gambar 1 berikut.

Gambar 1. Rasio Kemandirian Keuangan Daerah

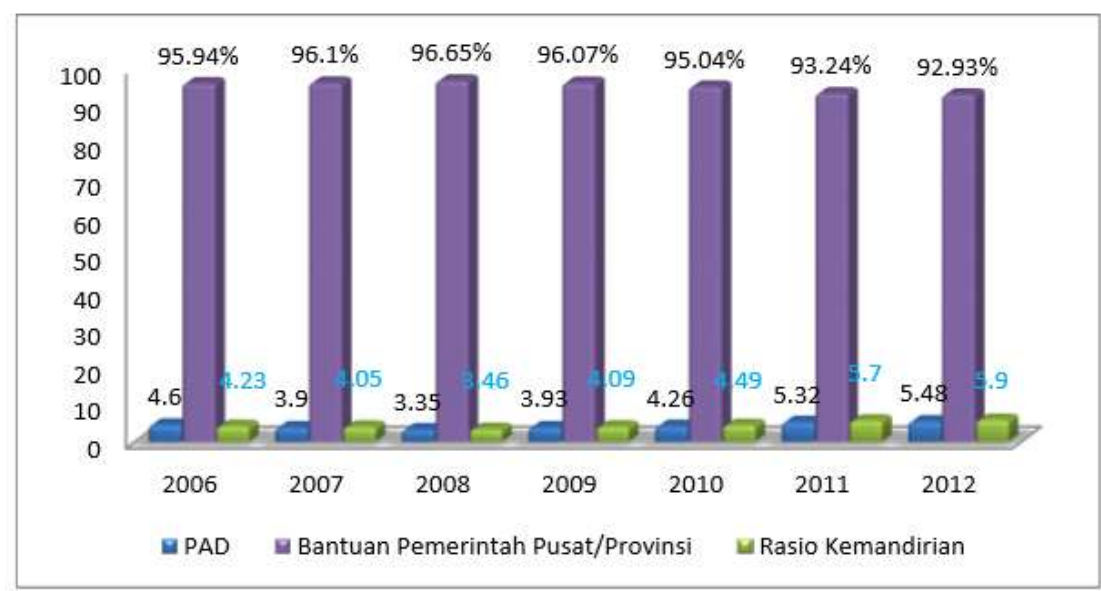

\section{Rasio Derajat Desentralisasi Fiskal}

Hasil perhitungan Rasio Derajat Desentralisasi Fiskal dapat dilihat dalam tabel berikut :

Tabel 6. Rasio Derajat Desentralisasi Fiskal Kabupaten Musi Rawas Tahun Anggaran 2006-2012

\begin{tabular}{|c|c|r|r|c|}
\hline $\begin{array}{c}\text { Tahun } \\
\text { Anggaran }\end{array}$ & $\begin{array}{c}\text { PAD } \\
\text { (Rp) }\end{array}$ & $\begin{array}{c}\text { TPD } \\
\text { (Rp) }\end{array}$ & (\%) & Keterangan \\
\hline $\mathbf{2 0 0 6}$ & $25.598 .297 .042,00$ & $631.166 .534 .687,00$ & 4,06 & Sangat Kurang \\
\hline $\mathbf{2 0 0 7}$ & $29.504 .973 .615,00$ & $757.248 .857 .584,00$ & 3,90 & Sangat Kurang \\
\hline $\mathbf{2 0 0 8}$ & $31.877 .920 .415,70$ & $952.025 .183 .382,00$ & 3,3 & Sangat Kurang \\
\hline $\mathbf{2 0 0 9}$ & $31.569 .268 .795,57$ & $804.084 .338 .660,57$ & 3,9 & Sangat Kurang \\
\hline $\mathbf{2 0 1 0}$ & $42.713 .015 .778,20$ & $1.001 .484 .266 .579,20$ & 4,26 & Sangat Kurang \\
\hline $\mathbf{2 0 1 1}$ & $65.469 .334 .676,97$ & $1.231 .376 .695 .408,97$ & 5,32 & Sangat Kurang \\
\hline $\mathbf{2 0 1 2}$ & $73.018 .397 .086,40$ & $1.332 .838 .864 .099,65$ & 5,48 & Sangat Kurang \\
\hline \multicolumn{5}{|c|}{ Rata-rata } \\
\hline
\end{tabular}

Sumber : Data diolah, 2014

Berdasarkan tabel 6 terlihat bahwa Rasio PAD terhadap TPD mengalami penurunan dari tahun 2006 sampai tahun 2008. Dimana pada tahun 2006 Rasio PAD terhadap TPD sebesar 4,06\% turun sebesar 3,90\% dan turun lagi menjadi 3,35\%. Setelah tahun 2009 sampai tahun 2012 Rasio PAD terhadap TPD terus meningkat. Dari tahun 2009 sebesar 3,93\% menjadi 5,48\% pada tahun 2012. Peningkatan tertinggi hanya terdapat pada tahun 2012 sebesar 5,48\%. Jika dilhat secara rata-rata, hasil rasionya adalah 4,33\%.

\section{Rasio Indeks Kemampuan Rutin}

Indeks Kemampuan Rutin yaitu Proporsi antara PAD dengan pengeluaran rutin tanpa transfer dari pemerintah pusat. Hasil perhitungan rasio Indeks Kemampuan Rutin dapat dilihat dalam tabel 5.4 dibawah ini : 
Jurnal Manajemen Terapan dan Keuangan (Mankeu) Vol. 9 No. 02, Agustus 2020

P-ISSN: 2252-8636, E-ISSN: 2685-9424

Tabel 7. Kontribusi PAD terhadap Pengeluaran Rutin Kabupaten Musi Rawas

Tahun Anggaran 2006-2012

\begin{tabular}{|c|c|c|c|c|}
\hline $\begin{array}{c}\text { Tahun } \\
\text { Anggaran }\end{array}$ & $\begin{array}{l}\text { PAD } \\
\text { (Rp) }\end{array}$ & $\begin{array}{l}\text { Pengeluaran Rutin } \\
\text { (Rp) }\end{array}$ & (\%) & $\begin{array}{c}\text { Kemampuan } \\
\text { Keuangan }\end{array}$ \\
\hline 2006 & $25.598 .297 .042,00$ & $318.886 .522 .827,00$ & 8,03 & Sangat Kurang \\
\hline 2007 & $29.504 .973 .615,00$ & $394.307 .326 .914,26$ & 7,48 & Sangat Kurang \\
\hline 2008 & $31.877 .920 .415,70$ & $486.111 .949 .000,00$ & 6,56 & Sangat Kurang \\
\hline 2009 & $31.569 .268 .795,57$ & $541.488 .972 .435,00$ & 5,83 & Sangat Kurang \\
\hline 2010 & $42.713 .015 .778,20$ & $705.424 .785 .938,00$ & 6,05 & Sangat Kurang \\
\hline 2011 & $65.469 .334 .676,97$ & $784.657 .293 .560,00$ & 8,34 & Sangat Kurang \\
\hline 2012 & $73.018 .397 .086,40$ & $766.654 .967 .160,00$ & 9,52 & Sangat Kurang \\
\hline \multicolumn{3}{|c|}{ Rata-rata } & 7,40 & Sangat Kurang \\
\hline
\end{tabular}

Sumber : Data diolah, 2014

Berdasarkan tabel 7 terlihat bahwa Rasio Pendapatan Asli Daerah terhadap Pengeluaran Rutin Daerah Kabupaten Musi Rawas dari tahun ke tahun menunjukan keadaan yang tidak stabil dan selalu berubah-ubah. Pada tahun 2006 dan 2007 rasio Indeks Kemampuan Rutin mencapai 8,03\% dan 7,43\%. Selanjutnya pada tahun 2008 mengalami penurunan menjadi 6,56\% dan pada tahun 2009 menurun lagi mencapai 5,83\%. Selanjutnya pada tahun 2010 sampai 2012 terus mengalami peningkatan, dimana pada tahun 2010 mencapai $6,05 \%$ mejadi 8,34\% pada tahun 2011 dan meningkat lagi pada tahun 2012 mencapai 9,52\%.

\section{Rasio Keserasian}

Hasil perhitungan analisis rasio keserasian dapat dilihat dalam tabel 5.5 berikut ini:

Tabel 8. Belanja Rutin, Pembangunan dan Total APBD Kabupaten Musi Rawas Tahun Anggaran 2006-2012

\begin{tabular}{|c|c|c|c|c|c|c|c|}
\hline \multirow{2}{*}{$\begin{array}{c}\text { Tahu } \\
\text { n }\end{array}$} & \multirow{2}{*}{$\begin{array}{c}\text { Total Belanja } \\
(\mathrm{Rp})\end{array}$} & \multicolumn{2}{|c|}{ Realisasi Belanja Rutin } & \multicolumn{2}{|c|}{ Realisasi Belanja Pembangunan } & \multirow{2}{*}{$\begin{array}{c}\text { Rasio } \\
\text { Belanja } \\
\text { Rutin } \\
(\%)\end{array}$} & \multirow{2}{*}{$\begin{array}{c}\text { Rasio } \\
\text { Belanja } \\
\text { Pembangu } \\
\text { nan } \\
(\%)\end{array}$} \\
\hline & & Rp. & $\begin{array}{c}\text { Perkem } \\
\text { bangan } \\
(\%)\end{array}$ & Rp. & $\begin{array}{c}\text { Perkem } \\
\text { bangan } \\
(\%)\end{array}$ & & \\
\hline 2006 & $516.870 .466 .529,03$ & $318.163 .886 .827,03$ & - & $197.983 .943 .702,00$ & - & $61,56 \%$ & $38,30 \%$ \\
\hline 2007 & $791.086 .571 .797,26$ & $393.795 .718 .914,26$ & 23,77 & $396.779 .244 .883,00$ & 100,41 & $49,78 \%$ & $50,16 \%$ \\
\hline 2008 & $932.895 .580 .055,60$ & $485.026 .425 .000,60$ & $23,17 \%$ & $446.783 .631 .055,00$ & 12,60 & $51,99 \%$ & $47,89 \%$ \\
\hline 2009 & $922.101 .566 .675,00$ & $540.611 .018 .685,00$ & $11,46 \%$ & $380.612 .594 .240,00$ & $(14,81)$ & $58,63 \%$ & $41,28 \%$ \\
\hline 2010 & $1.013 .642 .151 .954,00$ & $703.724 .885 .938,00$ & $30,17 \%$ & $308.217 .366 .016,00$ & $(19,02)$ & $69,43 \%$ & $30,41 \%$ \\
\hline 2011 & $1.114 .924 .593 .674,00$ & $782.183 .682 .060,00$ & $11,15 \%$ & $330.267 .300 .114,00$ & 7,15 & $70,16 \%$ & $29,62 \%$ \\
\hline 2012 & $1.214 .370 .857 .254,00$ & $766.621 .467 .160,00$ & $(1,99) \%$ & $447.715 .890 .094,00$ & 35,56 & $63,13 \%$ & $36,87 \%$ \\
\hline \multicolumn{6}{|c|}{ Rata-rata } & $60,67 \%$ & $39,22 \%$ \\
\hline
\end{tabular}

Sumber : Data diolah, 2014

Dari tabel 8 juga dapat dilihat rasio belanja rutin dan belanja modal yang belum stabil. Pada tahun 2006 rasio belanja rutin dan rasio belanja modal sebesar $61,56 \%$ dan $38,30 \%$. Sedangkan pada tahun 2007 rasio belanja rutin menurun menjadi 49,78\% dan rasio belanja pembangunan naik menjadi 50,16\%. Selanjutnya pada tahun 2008 rasio belanja rutin naik menjadi $51,99 \%$ dan rasio belanja peembangunan turun menjadi 47,89\%. Pada tahun 2009 rasio belanja rutin mengalami peningkatan sebesar 58,63\% dan rasio belanja pembangunan menurun menjadi 41,28\%. Kemudian pada tahun 2010 rasio belanja rutin naik $69,43 \%$ dan rasio belanja pembangunan turun mencapai $30,41 \%$. 
Selanjutnya tahun 2011 rasio belanja rutin meningkat sebesar $70,16 \%$ dan rasio belanja pembangunan menurun mencapai $29,62 \%$. Sedangkan pada tahun 2012 rasio belanja rutin turun $63,13 \%$ dan rasio belanja pembangunan naik $36,87 \%$.

\section{SIMPULAN DAN SARAN}

\section{Simpulan}

1. Berdasarkan Kontribusi PAD terhadap Anggaran Pendapatan Belanja Daerah Kabupaten Musi Rawas dalam mendukung upaya pelaksanaan otonomi daerah tahun anggaran 2006-2012 masih relatif rendah, dan rata-rata yang diperoleh hanya sebesar $4,33 \%$ dari total pendapatan APBD. Hal ini menunjukan bahwa PAD mempunyai peranan yang relatif rendah dalam mendukung upaya pelaksanaan otonomi daerah di Kabupaten Musi Rawas tahun anggaran 2006-2012.

2. Berdasarkan Rasio Kemandirian Keuangan Daerah menunjukan angka rata-ratanya sebesar $4,56 \%$ masih berada diantara $0 \%-25 \%$ tergolong mempunyai pola hubungan instruktif. Hal tersebut terlihat jelas menggambarkan masih besarnya tingkat ketergantungan pemerintah Kabupaten Musi Rawas terhadap dana transfer pemerintah pusat.

3. Berdasarkan Rasio Derajat Desentralisasi Fiskal, selama 7 (tujuh) tahun menunjukan angka rata-rata sebesar 4,33\% dengan kemampuan keuangan yang masih sangat kurang berada pada interval $0,00 \%$ - 10,00\%. Hal ini menunjukan bahwa Pemerintah Kabupaten Musi Rawas belum mampu membiayai pengeluarannya sendiri, dan masih bergantung dengan bantuan dari pemerintah pusat dalam membiayai daerahnya sendiri.

4. Berdasarkan kemampuan PAD untuk membiayai pengeluaran rutin daerah, yang sering disebut juga dengan IKR (Indeks Kemampuan Rutin) rata-rata hanya 7,40\% dengan pola kemampuan masih berada dalam interval $0,00 \%-20.00 \%$ yang sangat kurang. Hal ini menunjukan bahwa PAD belum mampu untuk membiayai belanja rutin yang dilakukan Pemerintah Kabupaten Musi Rawas.

5. Berdasarkan Rasio Keserasian terlihat bahwa pemerintah Kabupaten Musi Rawas lebih memprioritaskan belanja rutin daripada belanja pembangunan, hal ini terlihat dari ratarata rasio belanja rutin sebesar $60,67 \%$ sedangkan rasio belanja pembangunan hanya sebesar 39,22\% dari total belanja. Pemerintah Kabupaten Musi Rawas masih belum memperhatikan pembangunan daerah, dan lebih condong belanja rutin yang bersifat konsumtif daripada investasi.

\section{Saran}

Mengingat terbatasnya sumber-sumber penerimaan PAD, maka diperlukan penyerahan kewenangan beberapa sumber penerimaan yang potensial untuk dikelola dan dipungut sendiri oleh daerah dan menjadi PAD, seperti PPh (Pajak Penghasilan).

Pemerintah daerah harus mampu mengoptimalkan penerimaan dari potensi pendapatannya yang telah ada. Inisiatif dan kemauan pemerintah daerah sangat diperlukan dalam upaya meningkatkan PAD. Pemerintah daerah harus mencari alternatif-alternatif yang memungkinkan untuk dapat mengatasi kekurangan pembiayaannya, dan hal ini memerlukan kreaitifitas dari aparat pelaksana keuangan daerah untuk mencari sumbersumber pembiayaan baru baik melalui program kerjasama pembiayaan dengan pihak swasta dan juga program peningkatan PAD misalnya pendirian BUMD sektor potensial.

Pemerintah perlu meningkatkan intensifikasi penerimaan PAD, dengan mengoptimalkan semua sumber keuangan yang ada, salah satunya dengan pendirian Badan Usaha Milik Daerah (BUMD) sektor potensial yang berbentuk perusahaan daerah. 


\section{DAFTAR PUSTAKA}

Amir, Amri., Junaidi., Yulmardi. 2009. "Metodologi Penelitian Ekonomi dan Penerapannya”. Bogor: IPB PRESS.

Badan Pusat Statistik, 2013. Musi Rawas Dalam Angka 2013. Badan Pusat Statistik Kabupaten Musi Rawas.

Harmato Yuandhi Wibowo. 2006. "Analisis Kinerja Keuangan Daerah Sebelum dan Pada Masa Otonomi Daerah (Studi Kasus di Kabupaten Sragen Tahun Anggaran 1996/1997-2005)". Skripsi FE UNS Surakarta.

http://www.scribd.com/doc/101754251/JAUJ-Vol-09-No-2-Desember-2011diakses tanggal 28 April 2014

Mudrajad Kuncoro. 2000. Ekonomi Pembangunan (Teori, Masalah dan Kebijakan). Yogyakarta: UPP AMP YKPN.

Mulyanto. 2001. "Identifikasi dan Analisis Potensi Penerimaan Pajak dan Retribusi Daerah di Eks-Karesidenan Surakarta". Usul Penelitian Dosen Muda FE UNS Surakarta.

Mardiasmo. (2005), Pengertian Anggaran Pendapatan dan Belanja Daerah. http://elib.unikom.ac.id/download.php?id=178816. Di akses pada tanggal 28 April 2014.

Mahmudi. 2010. Buku Seri Membudayakan Akuntabilitas Publik: Analisis Laporan Keuangan Pemerintah Daerah Panduan bagi Eksekutif, DPRD, dan Masyarakat dalam Pengambilan Keputusan Ekonomi, Sosial, dan Politik. Yogyakarta: Unit Penerbit dan Percetakan Sekolah Tinggi Ilmu Manajemen YKPN.

Muhammad Syahlan AS. 2013. Analisis Kemampuan Keuangan Daerah Kabupaten Sarolangun Tahun 2006-2010. Universitas Jambi Kampus Sarolangun. Tidak diterbitkan.

Nataluddin. 2001. Potensi dana perimbangan pada pemerintahan daerali di Propinsi Jambi, Manajemen Keuangan Daerah. Yogyakarta: UPP YKPN

Peraturan Pemerintah Nomor 24 Tahun 2005 Tentang Standar Akutansi Pemerintah

Peraturan Pemerintah Nomor 58 Tahun 2005 Tentang Pengelolaan Keuangan Daerah

Peraturan Menteri Dalam Negeri Nomor 13 Tahun 2006 Tentang Pedoman Pengelolaan Keuangan Daerah

Republik Indonesia. 1999. Undang-Undang No. 22 Tahun 1999 Tentang Pemerintahan Daerah

Sarundajang. 2005. Birokrasi dalam Otonomi Daerah “Upaya Mengatasi Kegagalan”. Jakarta: Kata Hasta Pustaka.

Sholikhah Ratna. 2011. Analisis Kemampuan Kemandirian Keuangan Daerah Dan Pengaruhnya Terhadap Pertumbuhan Ekonomi Kabupaten Wonogiri Tahun Anggaran 2000-2009. (Online) (http://eprints.uns.ac.id/4979/1/208481611201104331.pdf diakses tanggal 19 May 2014).

Ulum, Ihyaul. 2009. Audit Sektor Publik Suatu Pengantar. Malang: Bumi Aksara.

Undang-Undang No. 17 Tahun 2003 Tentang Keuangan Negara

Undang-Undang No. 32 Tahun 2004 Tentang Pemerintahan Daerah

Undang-Undang No. 28 tahun 2009 Tentang Pajak Daerah Dan Retribusi Daerah

Undang-Undang No. 33 Tahun 2004 Tentang Perimbangan Keuangan Antara Pemerintah Pusat dan Pemerintah Daerah

Wulandari, Anita. 2001. Kemampuan Keuangan Daerah. Jurnal Kebijakan dan Adminislrasi Publik Vol 5 No 2 November. (Online) 